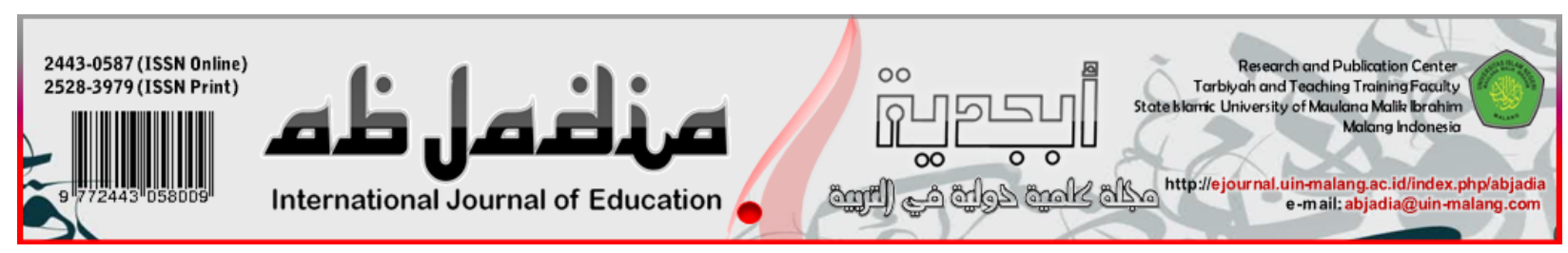

\title{
THE ONLINE LEARNING TRANSITION: CHALLENGES AND OPPORTUNITIES
}

\author{
Taufiq Satria Mukti, Sharfina Nur Amalina \\ Universitas Islam Negeri Maulana Malik Ibrahim Malang, Indonesia
}

\begin{abstract}
Article History:
Received : 2021-07-14

Revised : 2021-11-29

Accepted : 2021-12-08

Published : 2021-12-26
\end{abstract}

\section{Keywords:}

Online Learning, Psychological Aspects,

Health Aspects, Facilities and Infrastructure Aspects

*Correspondence Address:

tsatriam@uin-malang.ac.id

\begin{abstract}
Covid-2019 is still volatile. Restrictions on community activities have a broad impact on life, including education. Learning activities shift to online learning, causing psychological, health, infrastructure, and carrying capacity problems. This changing condition is a challenge and a challenge for students and educators. This study aims to find information about the challenges and opportunities in online learning so that the results of this study can provide policy recommendations in the implementation of learning in the following semester. This survey research was conducted by distributing a questionnaire (google form) to level 2 students at the State Islamic University of Maulana Malik Ibrahim Malang during three learning periods, namely the end of the even semester 2020/2021, odd semester 2021/2022, and even semester $2021 / 2022$ to the same students. Students dominate the results of each aspect during online learning. What is obtained from this research is that online learning has challenges to try and at the same time as an alternative problem solving on the quality of education. Educational policies during the online learning period must also deliver attention to the psychological condition of students so that their physical and spiritual health is maintained. The government and other relevant agencies can fully contribute to implementing quality online learning. One of them is controlling and providing an equitable network throughout Indonesia to create quality online learning.
\end{abstract}

\section{Introduction}

The 2019 Corona Virus Disease (covid-19) pandemic that hit all corners of the world, including Indonesia, caused changes in life behavior. No exception to changes in the implementation of education. Formal education from PAUD, TK, SMP/MTs, SMA/MA/SMK levels, and even higher education, which previously took place face-toface, are no longer implemented. Educational activities are now shifting to online learning from students' homes or Distance Learning (PJJ). It is regulated in the Minister of Education and Culture Decree Number 4 of 2020 because it considers the importance of avoiding and saving lives from the threat of COVID-19 for an indefinite period. This distance learning process utilizes the internet network where students can access material, discuss, and interact with educators virtually.

Online media in supporting online learning can be in the form of platforms developed by each institution/agency or utilizing Google facilities which can be accessed for free or by subscription. Implementing this online learning requires readiness both in 
terms of human resources (HR) and technology. For HR, they must inevitably be able to master technology, promote creativity and innovation in carrying out online learning (Keengwe \& Georgina, 2011). The research conducted (Khusniyah \& Hakim, 2019) is proof that in carrying out online learning, you must always prioritize creative and innovative learning so that learning is effective. Meanwhile, in terms of technology, both software and hardware must be capable or up-to-date (Gilbert, 2015) so that the learning process takes place well. Some of these devices that support online learning can be laptops/computers or mobile phones. In addition, no less important in supporting online learning, the main thing is a network or internet connection. It is this network or internet connection that determines the continuity of online learning. The better the network will undoubtedly increase the effectiveness of the implementation of online learning. The internet will help students access learning platforms, literature or references, or various learning resources that support online learning (Setiyani, 2010).

The readiness of human resources in mastering technology and the latest technology is a real challenge in online learning. Not only a challenge for students but also educators. Teachers and Lecturers both have challenges so that the implementation of online learning is effective and meaningful. These challenges must face by changing the mindset, being able to plan by compiling lesson plans well, predicting the right direction, and determining strategic steps to overcome the turmoil of change in learning (Harto, 2018). The main challenge is that in addition to making learning effective, it is necessary to emphasize that the learning that takes place is also fun and far from boring. The implementation effectiveness can be achieved by several other supporting factors, including design and financing (Sun \& Chen, 2016).

Educators need to pay attention that teaching materials in the implementation of online learning (1) are easy to access. Teaching materials in the form of soft files are not significant incapacity, so that they take a relatively short time to download and save internet quota more. (2) Based on applications that can be accessed offline, educators provide many learning media, but many are still online. It is a challenge and a severe opportunity because remembering when teaching materials can be accessed offline will reduce the dependence of the learning process on an internet connection. This challenge to the media is also an opportunity for educators who master technology to create and develop learning applications as totality and professionalism in providing educational services. Not only for educators, but this can also be an opportunity for professions other than educators, especially IT experts, to collaborate with educators in creating these offline learning applications.

The impact of online learning has an impact on students in Indonesia. In reality, many students complain about online learning. They faced many obstacles while carrying out online learning. The impact felt by students is that there is still a lack of understanding during learning. Students become less active and feel stressed because of their obstacles during online learning. A survey conducted by LPM (Quality Assurance 
Institute) Islamic State University Maulana Malik Ibrahim during online learning in Higher Education shows that the main obstacle is the internet network. In addition to network constraints, another obstacle is psychological factors in students. These obstacles are the main problems that can impact other aspects, namely health problems and reduce motivation to learn. Synchronous learning with e-learning that is carried out relatively long can make students stay in a static state for longer. The condition that they have to deal with a small screen of movement will be obvious to have less space to move their limbs a little. It tends to increase the risk of stress (Putri \& Mulyono, 2018). Stress is a physical, cognitive, emotional, and behavioral response to a situation that is considered threatening or challenging the individual (Ciccarelli \& White, 2015). However, each individual's stress response is different. The pressure and stress experienced by students are also caused by several other things, such as the enormous workload because many courses must be passed (Argaheni, 2020).

Psychological disorders for students are caused because they feel the learning is very burdensome and tedious. Learning is only a pile of tasks that must be completed in a short time. Meanwhile, for educators, the stress they face is time management for the interests of home or family and work. It is none other than during the online learning period, and educators carry out Work From Home (WFH).

The government has minimized internet access needs by assisting with data packages to meet internet access needs. This assistance is for students, but the entire academic community gets assistance from both teachers and lecturers (Kemendikbud Inaugurates Internet Data Quota Assistance Policy 2020, 2020). As a form of concern for national education, internet network providers are also doing the same thing by providing bonuses or cheap data packages. It is done so that online learning can continue. Service providers for the network simultaneously have challenges and opportunities to seek network expansion, especially in remote areas where there is no internet access or if there is already a minimal condition compared to urban areas or crowded centers.

Constraints that are personal to students can be treated according to their needs, such as coping with stress. Coping Stress is a treatment to tolerate, minimize, control, or reduce the impact of stress (Hanifah, Lutfia, \& Ramadhia, 2020). This method can be done by doing behavioral strategies and psychological strategies (Ciccarelli \& White, 2015). Stress coping can be done: 1) Problem-focused coping, a strategy to eliminate or change stressors by maintaining a healthy lifestyle with adequate nutritional intake and regular exercise, 2) Emotional-focused coping, a strategy that involves changing the way a person feels about stressors. This strategy reduces the emotional impact of the stressor and allows problem-solving in a more effective way (Hanifah et al., 2020)

In the results of research in one of the Unnes Journal of Public Health articles, it was written that working in front of a computer screen for a long duration would cause health problems, especially in the emergence of discomfort and fatigue in the eyes (Permana \& Koesyanto, 2015). Symptoms that often appear are cramps or back pain, headaches, 
increased heart rate, respiratory problems, to digestive problems (Putri \& Mulyono, 2018). These disorders can be caused by an improper sitting position and working for too long. Therefore, to reduce or prevent health problems during learning, it is recommended to stop for a moment to rest, especially the eyes, because it can reduce the level of discomfort (Kumasela, Saerang, \& Rares, 2013). It is also necessary to do light movements, stretches, or just standing, walking around the room.

Some of the problems in online learning are certainly a challenge, so thinking is needed to obtain accurate solutions and alternatives. Some of these obstacles also have positive values that can become opportunities. This is stated by (Bakia, Shear, Toyama, \& Lasseter, 2012) that distance learning will reduce financing in the implementation of education. This reason is viewed from the implementation of conventional/face-to-face learning, which requires various standard supporting facilities and infrastructure such as classrooms, tables, chairs, stationery, projectors, and others. Distance learning will undoubtedly be more flexible and reduce the cost of facilities and infrastructure.

The problems that exist in online learning are formulated into several aspects of the problems in the research. These aspects are carrying capacity in individual abilities/skills, health, psychology, and facilities and infrastructure. These four aspects are the main issues that will be explored in research conducted through surveys.

\section{[Q] Method}

Survey research was conducted on 2nd-grade students of FITK UIN Maulana Malik Ibrahim Malang. The student carries out online learning starting in the even half of the semester (February-June 2020/2021) and continuing until the even semester of 2021/2022 (time series). Online education for students in the transition from face-to-face learning to online learning. The transition period was due to the pandemic, so all learning activities were carried out online with careful consideration.

The research was conducted using a questionnaire as the main instrument in data collection, and then descriptive analysis was carried out to describe the phenomenon objectively. The questionnaire was designed using a scale of 1-5 or a Likert scale consisting of four aspects of the research problem. These aspects include carrying capacity, health, psychology, facilities, and infrastructure. Scale 1 indicates strongly disagree with the item, and scale 2 disagrees, scale 3 is undecided, scale 4 agrees, while scale 5 strongly agrees with the statement items and follows reality. Data collection was carried out during three learning periods: the end of the even semester 2020/2021, odd semester 2021/2022, and even semester 2021/2022 for the same students. Data collection using google forms aims to reduce mobility and interaction during the pandemic. Aspects, indicators, and questions in the questionnaire referred to in the study are as follows: 
Tabel 1. Research Instruments

\begin{tabular}{llc}
\hline \multicolumn{1}{c}{ Aspects } & \multicolumn{1}{c}{ Indicators } & Total Items \\
\hline Psychological & Learning Readiness & 5 \\
& Inner Change & 5 \\
& $\begin{array}{l}\text { Emotional \& } \\
\text { Motivation }\end{array}$ & 5 \\
Facilities and & Technology & 5 \\
Infrastructure & Body Health & 5 \\
Health & Financial ability & 5 \\
Carrying Capacity & Total Items & 40 \\
\hline \multicolumn{2}{c}{} \\
\hline
\end{tabular}

A survey of 4 aspects of the problem in the research presented via google form obtained as many as 307 respondents. The total items in each aspect are designed with a balanced number of positive and negative statements. It aims to determine the consistency of the research objectives in responding. Before the instrument is used in data collection, it is necessary to conduct a feasibility test. The feasibility test in question is the Validity Test through Expert Judgment or reviewing the contents of the questionnaire from three experts. Aiken's Validity Test Result is 0.833 , which means that the instrument meets good content validity and is suitable for data collection.

\section{Result}

\section{Psychological Aspect}

Psychological aspects are closely related to other parts of health problems that can hinder the learning process. Even though it is applied in a network or online and not face to face, the psychological aspect needs to be considered one of the implementations of implementing bold learning. The results of a survey on psychological aspects, which include three indicators, are as follows:

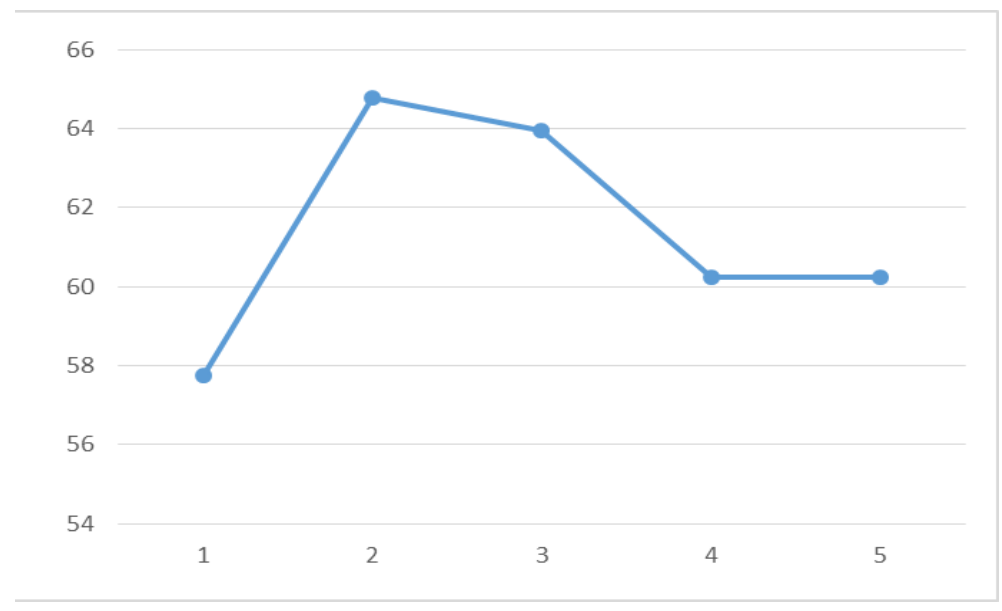

Figure 1. Psychological Aspect 
The survey results above can be interpreted that based on the psychological aspect, students generally feel that online learning is not able to provide what they expect. Of the seven positive items, $18.81 \%$ of respondents strongly disagreed, and $21.1 \%$ responded that they did not agree with the questionnaire items. A total of $19.63 \%$ of respondents each agreed and strongly agreed with the questionnaire items. However, at least $20.83 \%$ of respondents expressed doubt about the psychological conditions they experienced contained in the questionnaire.

\section{Facilities and Infrastructure Aspects}

The second aspect is a survey of aspects of facilities and infrastructure. The facilities and infrastructure are the primary tools and supports used during online learning. Without the supporting facilities and infrastructure, the implementation of online learning will be challenging to carry out smoothly. The results of the survey on the infrastructure and facilities aspects are as follows:

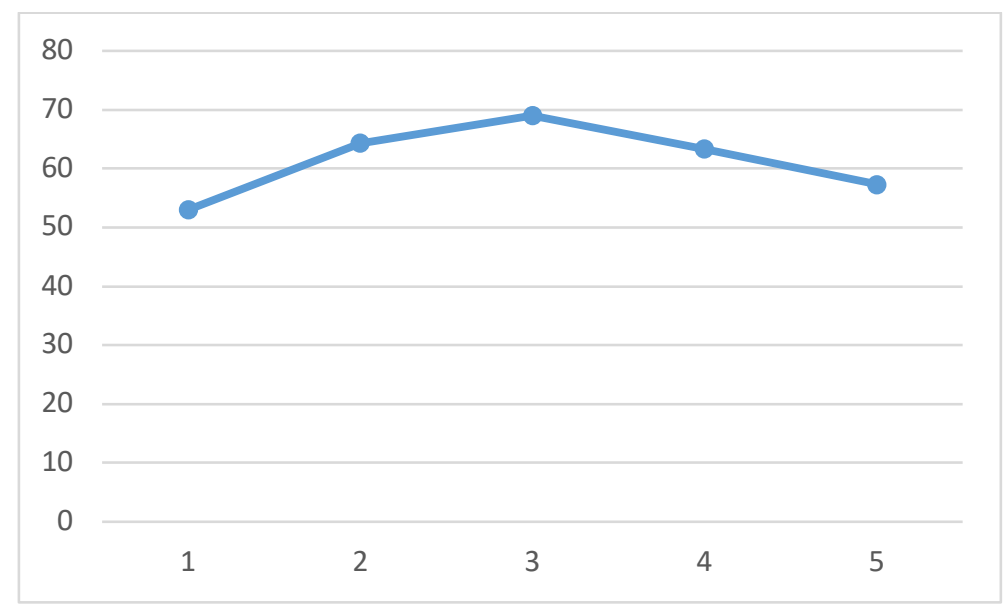

Figure 2. Aspects of Facilities and Infrastructure

Regarding facilities and infrastructure with network and technology indicators, the distribution of survey data looks like a normal distribution. That shows no significant difference in the percentage of respondents on a scale of 1 to 5 . On the positive items of the questionnaire, some respondents strongly disagree and disagree with the total rate of $17.26 \%$ and $20.96 \%$. In the response, agree as much as $20.63 \%$ and strongly agree $18.68 \%$. However, there were $22.48 \%$ gave a hesitant response to the questionnaire items.

\section{Health Aspect}

The health aspect is an essential support for the implementation of online learning. Without good health, the learning process will not take place. The following are the results of a survey on health aspects: 


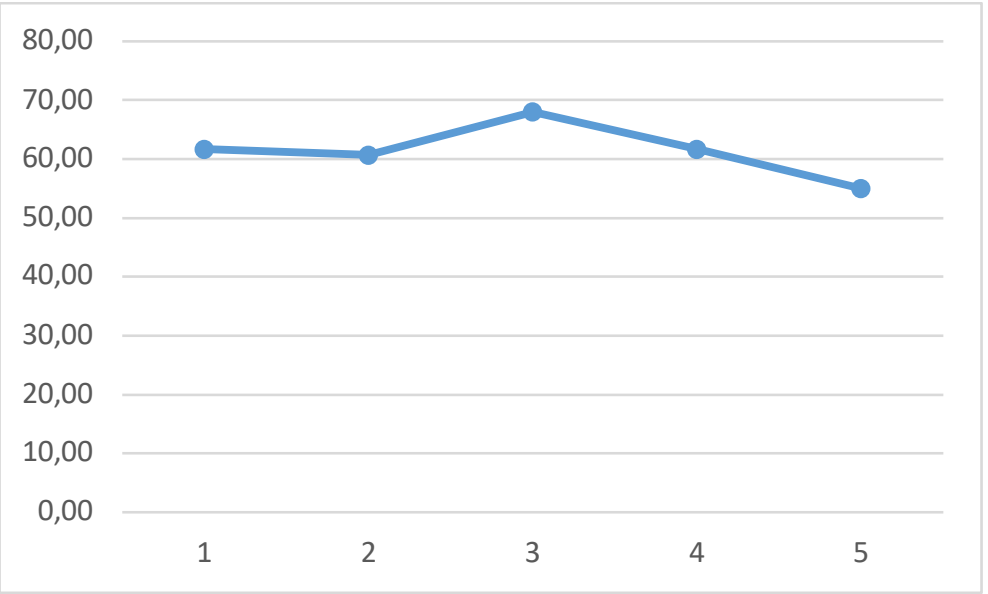

Figure 3. Health Aspect

In the health aspect, it can be seen that the distribution of research data shows conditions that are almost comparable between those who agree and those who disagree. However, this is a problem that online learning causes health problems for students. Health aspects generally contain negative statements. Figure 3 shows that $20.09 \%$ of respondents strongly disagree, meaning that the total percentage of respondents did not experience health problems. A total of $19.76 \%$ did not agree, and as much as $22.15 \%$ had doubts about his condition. The responses' statements agree and strongly agree with are $17.92 \%$ and $20.09 \%$, respectively. The percentage is the total respondents who experience health problems in themselves.

\section{Carrying Capacity Aspect}

The third aspect is the carrying capacity aspect. This aspect is a supporting aspect of online learning. Supportive capacity in the form of a smooth internet network, availability of internet quota during online learning, and the ability to master technology in online education. The survey on the carrying capacity aspect is presented as follows:

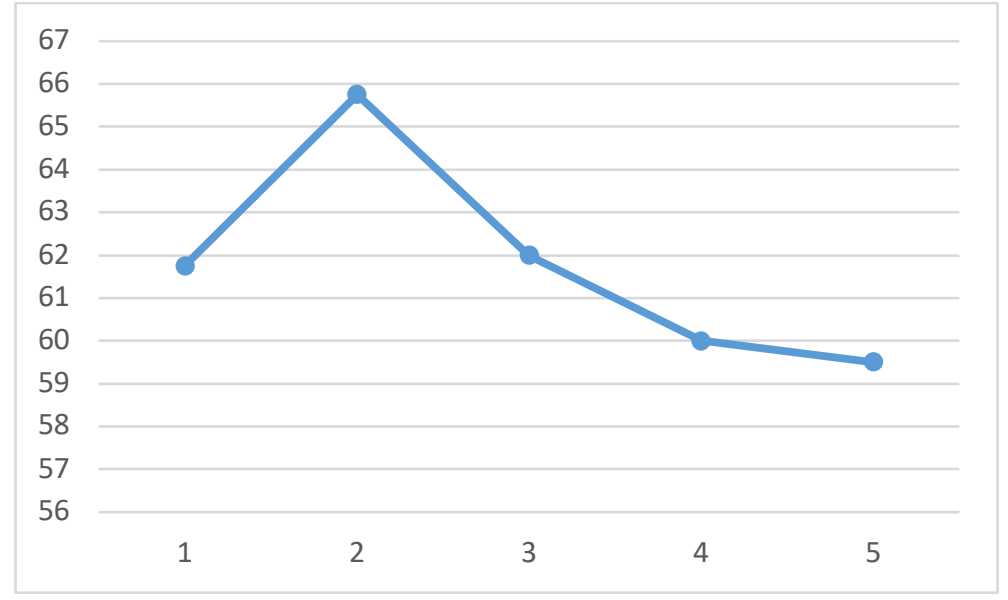

Figure 4. Carrying capacity

These results indicate that the average respondent has not fully mastered and understood 
the role and function of technology as a learning medium and an effective communication medium in distance learning. In Figure 4, as many as $19.84 \%$ of the responses strongly disagreed, and $21.14 \%$ opposed. It can be interpreted that this number of respondents do not have good skills during online learning. $20.16 \%$ of respondents said they doubted whether they had understood the role and function of technology or vice versa. However, the respondents who feel they know the role and function are 19.51 $\%$ with an agreeable response and $19.35 \%$ with a strongly agree or very confident response to the role and function of technology in remote learning.

\section{نَimiscussion}

The survey results on four aspects, including psychological aspects, infrastructure aspects, health aspects, and carrying capacity aspects, indicate that students are not satisfied with the implementation of online learning. On the psychological aspect, students feel less comfortable learning online continuously, both in terms of understanding the material presented, the effectiveness of online learning until there is discomfort to stress disorders, which also impact health aspects. The challenge for educators on the psychological aspect, which consists of learning readiness, inner change, and emotional motivation, should be in the learning process to carry out according to its portion - not continuously giving assignments. Educators must take on many roles, one of which is increasing creativity in online learning. Creative and innovative learning will undoubtedly reduce student boredom in education. That will also reduce the level of stress on students.

Educators must also master technology. Good mastery of technology will have a significant impact in implementing effective learning. Educators and students should also be able to manage themselves, organize, and divide time between work at home to help parents and provide independent study time as appropriate. From the psychological aspect, there are many opportunities to develop themselves and become good learners from the perspective of educators and students. There is much online training on various competencies for both teachers and students during the pandemic. There is no need to go out to issue travel transportation accommodations with online conditions. Even many are free, so several institutions or agencies hold training to improve the quality of learning. Both educators and students are aware and willing to follow their primary duties and responsibilities on the sidelines.

The findings (Wahyono \& Husamah, 2020) stated that from the beginning, the policy to implement online learning was still a lot, only giving assignments during the learning process without prioritizing the element of meaning in education, this was still relatively high, reaching $40 \%$. Online learning was initially carried out to make students enthusiastic by not requiring them to leave the house. This is supported by research results (Windhiyana, 2020) that the learning process with the Conference platform is 
declared effective. However, after several months to one semester, there are many obstacles and learning inconveniences Online. That will also continue as long as online learning is still implemented.

Student dissatisfaction is even felt by educators who should open up opportunities to make online learning more efficient. In the survey on aspects of facilities and infrastructure, many students still expressed doubts about the facilities and infrastructure questionnaire. The facilities and infrastructure here are the primary tools and supports in online learning, such as the devices used in education. However, the condition of these facilities and infrastructure is individual. With one another, the conditions will be different. In the study (Windhiyana, 2020), it was also found that the factors that dominate the effectiveness of the online learning process are the facilities and infrastructure, which in each student include different device capacities from one another.

Facilities and infrastructure are a big challenge for educators and students. Every learner, educator, and student should have a capable device in online learning. A device in the form of a capable laptop or computer will undoubtedly increase work effectiveness. However, what is no less important is the ability to master the device/technology. Both students and educators must be aware that the knowledge of digital literacy is essential to achieve quality learning in the current era. However, ownership of this device is closely related to economic conditions. Economic conditions will be the basis for compliance with supporting online learning. Thus, the alternative to this condition is to have at least a supporting device that is still suitable for use.

In addition, the condition of facilities and infrastructure also includes aspects of area coverage and the location of residence for each student. We know that not all areas have access to a good and stable internet network. Some interior, outermost, and remote regions are still very difficult to access networks or the internet. The extent of this area's coverage is based on UIN 2020 Academic data that UIN students are spread from all parts of Indonesia, from Sabang to Merauke.

This condition, if observed, is an opportunity for several parties. One of the vital parties is the government. The government has an excellent opportunity to improve services to the community as a form of implementation of the Pancasila mandate, which is to educate the nation's life. One of the concrete steps to inform the nation's life is that the government invites all elements of education and institutions to provide services to increase learning effectiveness. It shouldn't just be giving internet quota assistance. However, equitable distribution of conditions in Indonesia from Sabang to Merauke is a priority to obtain a good network and literacy.

The aspect of carrying capacity is a factor in the effectiveness of online learning. The biggest challenge is digital literacy or technology. Digital literacy skills will significantly support the implementation of online learning. Most students and lecturers have mastered technology, but there is still a lack of support for online learning. This finding 
is also as stated (Surahman et al., 2020) that the obstacles experienced by educators are due to generational differences and age factors. On average, educators who face obstacles lack digital skills in managing online learning. However, for the digitally literate generation, in this case, those in the young category, online learning is not the slightest obstacle.

Another obstacle that arises is the internet quota used while online. In fact, in a day, students have to take whole learning through the network. That is also a previous finding conducted by research (Widodo, 2020). Quotas are a problem, especially some of them are in areas where it is sometimes still difficult to get a signal. That will impact understanding the material and the freedom to access information online. Online learning has many weaknesses and shortcomings, especially for practice-based learning and materials containing calculations that will be more difficult to understand. Thus, the four aspects that are the primary support for the implementation of online education must be improved to support the online teaching and learning process at home.

Online learning with several obstacles experienced is a challenge for the entire academic community. However, if observed and studied correctly, of course, there will be many opportunities. Self-awareness and the ability to detect challenges and opportunities will help realize and increase high learning independence (Sadikin \& Hamidah, 2020). Of course, this independence will be recognized if there is increased motivation and enthusiasm for learning, adequate facilities, infrastructure, and supporting capacity for students.

\section{第 Conclusion}

Based on the research carried out on the four indicators, it can be concluded that the implementation of online learning impacts being unsatisfied for students. The learning carried out provides challenges for students and educators. Challenges to the psychological aspects related to health require teachers to have high creativity and innovation to carry out fun learning. Another aspect that becomes a challenge for online learning is supporting facilities and infrastructure such as the equipment owned, internet network (internet quota), and the ability possessed in mastering technology. Both students and educators must face challenges in online learning, and these existing challenges can be transformed into opportunities to improve policies and the quality of online learning.

\section{Bibliography}

Amrulloh, M. A., \& Basyori, A. (2019). The Effectiveness Of Using Interactive Video In Teaching Arabic Calligraphy. Abjadia, 4, 37-46.

https:/ / doi.org/10.18860/abj.v4i1.5999 
Argaheni, N. B. (2020). Sistematik Review: Dampak Perkuliahan Daring Saat Pandemi COVID-19 Terhadap Mahasiswa Indonesia. PLACENTUM: Jurnal Ilmiah Kesehatan dan Aplikasinya, 8(2), 99. https://doi.org/10.20961/placentum.v8i2.43008

Bakia, M., Shear, L., Toyama, Y., \& Lasseter, A. (2012). Understanding the Implications of Online Learning for Educational Productivity. USA: U.S. Department of Education. Retrieved from http://www.ed.gov/technology

Ciccarelli, S. K., \& White, J. N. (2015). Psychology. Georgia College \& State University: Pearson.

Efendi, M., Masriyah, M., \& Riadi, S. (2020). Islamic Contribution In The Covid-19 Pandemic Viewed From History. Abjadia, 5(2), 157-165. https://doi.org/10.18860/abj.v5i2.10335

Gilbert, B. (2015). Online Learning Revealing the Benefits and Challenges (Thesis, St. John Fisher College). St. John Fisher College. Retrieved from https://fisherpub.sjfc.edu/education_ETD_masters/303

Hanifah, N., Lutfia, H., \& Ramadhia, U. (2020). Strategi Coping Stress Saat Kuliah Daring Pada Mahasiswa Psikologi Angkatan 2019 Universitas Andalas. JURNAL PSIKOLOGI, 15.

Harto, K. (2018). Tantangan Dosen Ptki Di Era Industri 4.0. Jurnal Tatsqif, 16(1), 1-15. https://doi.org/10.20414/jtq.v16i1.159

Keengwe, J., \& Georgina, D. (2011). The Digital Course Training Workshop for Online Learning and Teaching. Springer Science+Business Media, LLC 2011, 365-379. https:/ / doi.org/10.1007/s10639-011-9164-x

Khusniyah, N. L., \& Hakim, L. (2019). Efektivitas Pembelajaran Berbasis Daring: Sebuah Bukti Pada Pembelajaran Bahasa Inggris. Jurnal Tatsqif, 17(1), 19-33. https:/ / doi.org/10.20414/jtq.v17i1.667

Kumasela, G. P., Saerang, J. S. M., \& Rares, L. (2013). Hubungan Waktu Penggunaan Laptop Dengan Keluhan Penglihatan Pada Mahasiswa Fakultas Kedokteran Universitas Sam Ratulangi. Jurnal e-Biomedik, 1(1). https:/ / doi.org/10.35790/ebm.1.1.2013.4361

Mustika Anggraini, D., \& Walid, M. (2016). Developing Interactive Flash Mediafor Thematic Learning. Abjadia, 1(1), 16. https://doi.org/10.18860/abj.v1i1.3256

Permana, M. A., \& Koesyanto, H. (2015). Faktor Yang Berhubungan Dengan Keluhan Computer Vision Syndrome (CVS) Pada Pekerja Rental Komputer Di Wilayah Unnes. Unnes Journal of Public Health, 10.

Putri, D. W., \& Mulyono, M. (2018). Hubungan Jarak Monitor, Durasi Penggunaan Komputer, Tampilan Layar Monitor, Dan Pencahayaan Dengan Keluhan 
Kelelahan Mata. The Indonesian Journal of Occupational Safety and Health, 7(1), 1. https:/ / doi.org/10.20473/ijosh.v7i1.2018.1-10

Sadikin, A., \& Hamidah, A. (2020). Pembelajaran Daring di Tengah Wabah Covid-19. BIODIK, 6(2), 109-119. https:/ / doi.org/10.22437/bio.v6i2.9759

Setiyani, R. (2010). Pemanfaatan Internet Sebagai Sumber Belajar. 17.

Sun, A., \& Chen, X. (2016). Online Education and Its Effective Practice: A Research Review. Journal of Information Technology Education: Research, 15, 157-190. https:/ / doi.org/10.28945/3502

Surahman, E., Santaria, R., \& Setiawan, E. I. (2020). TANTANGAN PEMBELAJARAN DARING DI INDONESIA. 5, 10.

Wahyono, P., \& Husamah, H. (2020). Guru profesional di masa pandemi COVID-19: Review implementasi, tantangan, dan solusi pembelajaran daring. 1(1), 15.

Widodo, A. (2020). Problematika Pembelajaran Daring Dalam Perspektif Mahasiswa. 4, 16.

Windhiyana, E. (2020). Dampak Covid-19 Terhadap Kegiatan Pembelajaran Online Di Perguruan Tinggi Kristen Di Indonesia. Perspektif Ilmu Pendidikan, 34(1), 1-8. https:/ / doi.org/10.21009/PIP.341.1 